\title{
Affect of sevofluranein on the developmental hippocampal neurons of rats and its possible mechanism.
}

\author{
Pei Xia Yu ${ }^{1}$ Lijun Bo ${ }^{2}$, Fuzhen Zhang², Zhenming Dong ${ }^{2 *}$ \\ ${ }^{1}$ Department of Anesthesiology, Third Hospital of Hebei Medical University, Shijiazhuang, Hebei Province, PR China \\ ${ }^{2}$ Department of Anesthesiology, Second Hospital of Hebei Medical University, Shijiazhuang, Hebei Province, PR China
}

\begin{abstract}
Objective: To study the effect of sevofluranein on the developmental hippocampal neurons of rats and the possible mechanism.

Methods: Hippocampal neurons were harvested from within $24 \mathrm{~h}$-old Sprague-Dawley rats and cultured in the different media. Then Hippocampal neurons were randomly divided into 4 groups and treated with air (control group, CG), sevofluranein (1 minimum alveolar concentration) for $3 \mathrm{~h}$ (S3 group), $6 \mathrm{~h}$ (S6 group), $12 \mathrm{~h}$ (S12 group) respectively. Average neurite length and mean optical density (MOD) were used as statistical indexed and detected. Proliferation was quantified by flow cytometry. BDNF and TrkB protein expression were assessed by Western blot.

Results: Average neurite length and MOD showed the same result between S3 group and CG (P>0.05), while the opposite result appeared in $\mathrm{S6}$ group and $\mathrm{S12}$ group $(\mathrm{P}<\mathbf{0 . 0 5})$. S6 group decreased with significant difference compared with $S 3$ group and S12 group $(P<0.05)$. Compared with $C G$ and S3 group, neuronal apoptosis rate in $\mathrm{S6}$ group and $\mathrm{S12}$ group increased $(\mathrm{P}<0.05)$. BDNF and TrkB protein expression in S6 group and S12 group was lower than those in CG, while that in S3 group was higher $(\mathbf{P}<0.05)$ and gray value had the same result.

Conclusion: The effect of sevoflurane on hippocampal neurons in vitro is bidirectional which may be related to the time through the BDNF-TrkB pathway.
\end{abstract}

Keywords: Sevoflurane, Hippocampal neurons, Neuroprotection, Neurotoxicity, Mechanism.

Accepted on November 27, 2017

\section{Introduction}

In America, approximately 6 million children, including newborns, undergo general anaesthesia each year [1]. In China, this number is much more. The effects of general anaesthesia drugs on children have become one of the most watched issues. In previous reports, anaesthetics have neuroprotective effects on new-borns [2]. However, the cytotoxic effects of neonatal anaesthesia have also been mentioned in a large number of studies [3]. Multiple studies demonstrated that anaesthetics induce neurotoxicity in the developing brain [4,5]. Long-term exposure to sevoflurane causes neurologic disorders in infants and the developing brain [6]. In animal, general anaesthetics caused neurological and cognitive deficits in rodents [7-9].

Volatile anaesthetics such as isoflurane, desflurane, sevoflurane, due to the rapid onset and short recovery time, have been commonly used in neonates and infants. Sevoflurane is a commonly used inhaled aesthetic, which provided amnesia, unconsciousness, and immobility by interfering with $\gamma$ aminobutyric acid receptor sub-type A, N-methyl-D-aspartate acid receptor, and glycine receptor [10].
Brain-derived neurotrophic factor (BDNF) is a member of the neurotrophin family of growth factors, which are related to the canonical nerve growth factor and active in the hippocampus, cortex, basal forebrain-areas vital to learning, memory, and higher thinking [11]. The activation of the BDNF-TrkB pathway is important in the development of short term memory and the growth of neurons. At present, a study presents that the 6 th day rats were exposed to $3 \%$ sevoflurane every day for 3 times, showing degeneration of neurons and abnormal cognitive function [12].

Based on the above result, we try to investigate the effect of sevofluranein on the hippocampal neurons from $24 \mathrm{~h}$-old rats and confirm whether it is related to the BDNF-TrkB pathway.

\section{Materials and Methods}

This study protocol was approved by the Ethics Committee of Hebei Medical University, and the experiment was performed in accordance with the Guidelines for the Care and Use of Laboratory Animals from the National institutes of Health, USA. Within 24 h-old Sprague-Dawley (SD) rats (4.0-6.5 g) were purchased from the Hebei Medical University Laboratory Animal Company (No:1408088). 
According to the literature method [13], hippocampal tissue was dissected from rat stripping the veins and membranes and removed into papaya enzyme for $30 \mathrm{~min}$ at $37^{\circ} \mathrm{C}$ with $5 \% \mathrm{CO}_{2}$. Then the tissue mass was immigrated into DMEM containing $10 \%$ serum for ending digestion twice ( 2 min per time). After sieved, the isolated cells were seeded at $1 \times 10^{6}$ cells $/ \mathrm{ml}$ cell suspension, transferred to 24 well plates coated with Matrigel basement membrane $\left(500 \mu \mathrm{l}\right.$ per well), cultured at $37^{\circ} \mathrm{C}$ with $5 \% \mathrm{CO}_{2}$. Six $\mathrm{h}$ later, medium was changed to serum-free neurobasal medium totally, and then the medium was renewed half quantity every 2 days during the culture process.

At the 6th day, hippocampal neurons were randomly divided into 4 groups and treated with air (control group, CG), sevofluranein (1minimum alveolar concentration, $1 \mathrm{MAC}$ ) for $3 \mathrm{~h}$ (S3 group), $6 \mathrm{~h}$ (S6 group), $12 \mathrm{~h}$ (S12 group) respectively. Hippocampal neurons were placed into a sealed glass container with inlet and outlet ports. An anaesthesia machine (Primus, Drager, Germany) was connected to the inlet port, which allowed sevoflurane to enter and detected the concentration (1 MAC).

After $12 \mathrm{~h}$, hippocampal neurons were moved back to medium for continuous culture. Medium samples were randomly collected for $\mathrm{pH}$ measure and corrected according to the $\mathrm{PH}$ of CG. Cultured for $24 \mathrm{~h}$, hippocampal neurons were randomly selected for vision pictures, and 5 pictures were taken and analysed with Motic Med 6.0. The average neurite length in the field was measured as a statistical index.

\section{Immunofluorescence}

24 well plates at 6 th day were taken out, washed with PBS for 3 times ( 2 min per time), fixed with $4 \%$ Paraformaldehyde for $2 \mathrm{~h}$, washed with PBS for 3 times ( $5 \mathrm{~min}$ per time), trans parented with $0.3 \%$ TritonX-100 for $15 \mathrm{~min}$, washed with PBS for 3 times ( 5 min per time), incubated with $10 \%$ goat closed serum for $30 \mathrm{~min}$ at $37^{\circ} \mathrm{C}$. After serum was removed, $200 \mathrm{ml} /$ well rabbit synaptophysin antibody (1:100, Epitomics, USA) were added and incubated at 4 overnight, followed by addition of DyLight 594-conjugated mouse anti-rabbit IgG (1:100, KPL, USA). DAPI ( $1 \mu \mathrm{g} / \mathrm{ml}$, ENZO, USA) was used for counterstaining. Mean optical density (MOD) of was picture was measured under a fluorescence microscope, analysed with MoticMed 6.0.

\section{Flow cytometry}

$0.1 \mathrm{ml}$ hippocampal neurons of each group was taken and added $1 \mathrm{ml}$ propidium iodide dye liquor for $30 \mathrm{~min}$ colouring avoiding light at 4 refrigerators. Single cell suspension was got after filtered with 500 mesh copper mesh, measured by EpicsXL II Flow cytometry (Beckman Coulter, USA), and analysed by Muticycle AV software.

\section{Western blot}

For protein extraction, hippocampal neurons were washed twice with PBS and lysed in appropriate amounts of radio immune-precipitation assay (RIPA) buffer. Protein was determined using bicinchoninic acid (BCA) method according to the instructions of BCA test kit. Equal amounts of protein were denatured and separated on 10\% SDS-PAGE gels, and transferred onto polyvinylidene difluoride membranes (PVDF) (Bio-Rad, Hercules, CA) membranes at $100 \mathrm{~V}$ for $2 \mathrm{~h}$.

After blocking with skim milk (5\%), proteins were incubated with respective primary antibodies in blocking solution at $4{ }^{\circ} \mathrm{C}$ overnight: anti-BDNF (1:100, Abcam) and anti-TrkB (1:100, Affinity). Primary antibody binding was detected with antimouse or rabbit secondary antibodies (1:5000) and visualized with enhanced chemiluminescence. Immunoreactive bands were photographed using Chemi Scope Capture, and relative band densities for various proteins were measured from the scanned films with Gel Image Analysis V2.02. $\beta$-actin was used as a loading control.

\section{Statistical analysis}

Data analysis was performed using SPSS for Windows software (Version 19.0; SPSS, Chicago, IL, USA). Data were presented as mean \pm standard error of standard deviation (SD). Differences between multiple means were assessed by Student's t-test or one-way analysis of variance (ANOVA) followed by a Turkey test if appropriated. $\mathrm{P}<0.05$ was considered statistically significant.

\section{Results}

The purity of hippocampal neurons in this study was $94.81 \pm$ $1.90 \%$. Average neurite length and MOD were significantly reduced by 1 MAC sevoflurane-exposure for $6 \mathrm{~h}$ and $12 \mathrm{~h}$ $(\mathrm{P}<0.05$, Table 1). This indicated that $1 \mathrm{MAC}$ sevoflurane can change the development of neurons and dendrites. However, sevoflurane did not induce significant changes between $\mathrm{CG}$ and $\mathrm{S} 3$ group in average neurite length and MOD $(\mathrm{P}>0.05$, Table 1).

Table 1. The average neurite length and MOD in each group $(\bar{x} \pm S D$, $n=5$ ).

\begin{tabular}{lll}
\hline Group & $\begin{array}{l}\text { Average neurite } \\
\text { length (um) }\end{array}$ & MOD \\
\hline $\mathrm{C}$ & $138.9 \pm 6.6^{\mathrm{b}}$ & $30.2 \pm 1.4^{\mathrm{b}}$ \\
\hline $\mathrm{S} 3$ & $138.1 \pm 7.7$ & $28.9 \pm 1.5$ \\
\hline $\mathrm{S} 6$ & $110.8 \pm 5.4^{\mathrm{ab}}$ & $23.7 \pm 1.8^{\mathrm{ab}}$ \\
\hline $\mathrm{S} 12$ & $102.6 \pm 6.2^{\mathrm{b}}$ & $19.1 \pm 0.7^{\mathrm{b}}$
\end{tabular}

Compared with control group, ${ }^{a}$ means $\mathrm{P}<0.05$; Compared with $\mathrm{S} 3$ group, ${ }^{b}$ means $\mathrm{P}<0.05$; MOD: Mean Optical Density.

Neuronal apoptosis rate was increased in S6 group and S12 group ( $\mathrm{P}<0.05$, Table 2). Gradual extension of treatment time caused significantly higher effects on neuronal apoptosis. There was no significant difference between $\mathrm{S} 3$ group and $\mathrm{CG}$ $(\mathrm{P}>0.05$, Table 2$)$.

Table 2. The apoptosis and cycle in each group $(\bar{x} \pm S D, n=3)$. 


\begin{tabular}{lllll}
\hline \multirow{2}{*}{ Group } & \multicolumn{2}{l}{ Phases of cell cycle } & \multicolumn{2}{l}{$\begin{array}{l}\text { Proliferation } \\
\text { index }(\%)\end{array}$} \\
\cline { 2 - 4 } & $\mathrm{G}_{0} / \mathrm{G}_{1}(\%)$ & $\mathrm{S}(\%)$ & $\mathrm{G}_{2} / \mathrm{M}(\%)$ & \\
\cline { 1 - 4 } $\mathrm{C}$ & $85.7 \pm 1.15$ & $8.6 \pm 0.89$ & $5.6 \pm 0.35$ & $14.2 \pm 1.09$ \\
\hline $\mathrm{S} 3$ & $83.7 \pm 0.93$ & $9.9 \pm 0.58$ & $6.3 \pm 0.52$ & $17.1 \pm 0.85$ \\
\hline $\mathrm{S} 6$ & $66.4 \pm 1.65^{\mathrm{ab}}$ & $29.2 \pm 1.13^{\mathrm{ab}}$ & $4.6 \pm 0.67$ & $33.7 \pm 2.31^{\mathrm{ab}}$ \\
\hline $\mathrm{S} 12$ & $54.1 \pm 3.57^{\mathrm{ab}}$ & $44.3 \pm 1.77^{\mathrm{ab}}$ & $4.8 \pm 0.36$ & $47.6 \pm 1.86^{\mathrm{ab}}$ \\
\hline
\end{tabular}

Compared with control group, ameans $\mathrm{P}<0.05$; Compared with S3 group, ${ }^{b}$ means $\mathrm{P}<0.05$

Compared with the control group, significantly decreased protein expression of BDNF and TrkB was observed after treatment with sevoflurane for 6 and $12 \mathrm{~h}(\mathrm{P}<0.05$, Figure 1$)$; while sevoflurane exposure for $3 \mathrm{~h}$ with increased protein expression of BDNF and TrkB in $\mathrm{S} 3$ group $(\mathrm{P}<0.05$, Figure 1$)$. Gray value of reference $\beta$-actin band in each group showed no significant difference $(\mathrm{P}>0.05)$.

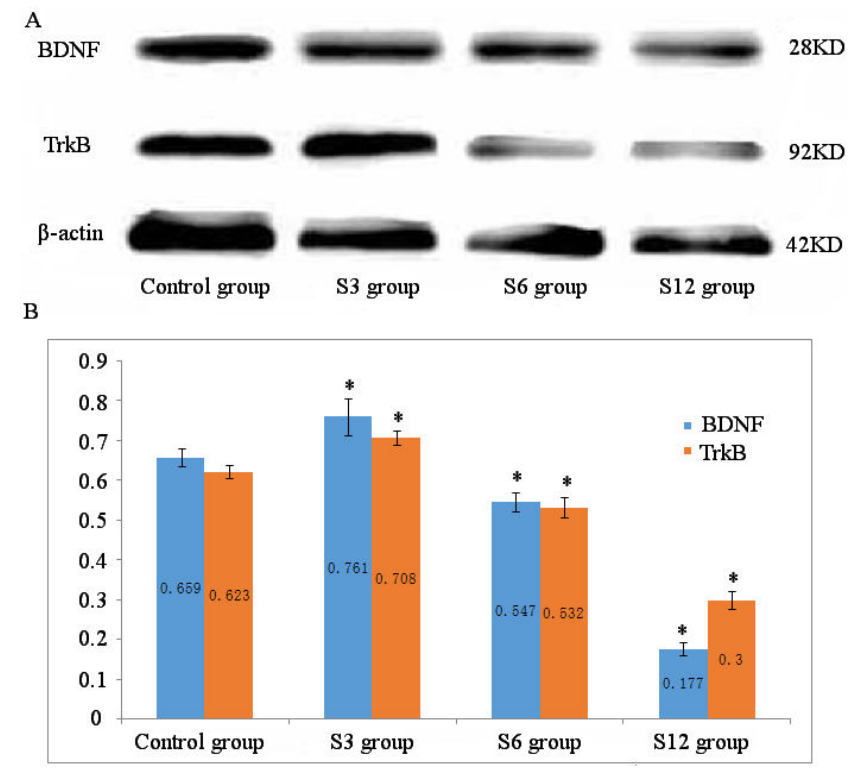

Figure 1. The expression of BDNF and TrkB in each group $(n=5)$; $* P<0.05$ compared with the control group; $A$ is representative Western blot of BDNF, TrkB and $\beta$-actin; $B$ is the quantitative analysis of the ratio of $B D N F$ to $\beta$-actin, the ratio of TrkB to $\beta$-actin.

\section{Discussion}

Sevoflurane was first discovered by Ross Terrell, which was synthesized by Regan in 1968 and completed phase-III clinical trials in 1986. In recent years; many famous anaesthesiology experts sew it as milepost type drug in inhalation anaesthesia. Multiple studies have demonstrated that sevoflurane is very helpful for reducing perioperative mortality [14]. However, this study showed that sevoflurane exposure for 6 or $12 \mathrm{~h}$ induced significant and persistent decrease of average neurite length and MOD. And, no significant effect was found between 0 and $3 \mathrm{~h}$ in these parameters. To a certain extent, these findings demonstrated that sevoflurane exposure beyond $6 \mathrm{~h}$ induces destruction of neuronal development and confirmed that 1
MAC sevoflurane could cause apoptosis in developing hippocampus neurons, altering their development in a timedependent manner.

It is well known that the nervous system of human is rapidly developed in the middle of pregnancy (18 weeks) until 2 years after birth [15]. In this period, if affected by external factors, the nervous system is easy to be damaged or destructed. The rats were often used to study in basic research. For the differences among species, the nervous system of rats was rapidly developed at $0-25$ th day after birth. Thus, this study chose 24 h-old rat and 6 days hippocampal neurons cultured in vitro as investigated object. The hippocampal neuron in this period is very close to the rapid development of the human brain, which is most sensitive and vulnerable to external stimuli such as anaesthetics [16].

A large number of studies suggested that a large proportion of interneurons are cleared by apoptosis during synapse formation in the central nervous system [17]. Some scholars believed that in the development of the nervous system, excessive apoptosis of nerve cells also affects the development of the central nervous system [18]. When apoptotic neurons were found in the dentate gyrus and hippocampus, apoptosis may affect their physiological functions, including learning and memory [19]. Indeed, it has previously been reported that inhalational anaesthetics, such as isoflurane and sevoflurane, caused neurological disorders in rats and mice [20], which was in line with our result. Although $6 \mathrm{~h}$ of primary neurons culture, if converted into exposure time in paediatric patients will be very long, the clinical dose of sevoflurane in children, especially infants, may cause security risks in clinical anaesthesia in the relevant people.

In the past several decades, neuroscientists have found many possible mechanisms for inhalational anaesthesia-induced apoptosis of hippocampal neurons. Recent reports suggested that NMDA receptor antagonists, GABA receptor agonists, and BDNF could affect the development of hippocampal neurons [21]. However, the mechanisms of sevoflurane-induced discrepant effects in developmental hippocampal neurons are currently unknown. BDNF is a protein related to neuronal survival, differentiation, and several forms of synaptic plasticity in the immature brain. On the other hand, BDNF is a curial regulator of neuronal survival and neuroplasticity in the brain [22]. TrkB is a receptor for brain-derived neurotrophic factors. BDNF binds TrkB, regulating neuronal development and plasticity, long-term potentiation, and apoptosis [23]. Meanwhile, BDNF-TrkB activates serine/threonine-specific protein kinase (Akt), promoting neuronal survival [24]. Thus, the BDNF-TrkB pathway via PI3K/Akt regulates neuronal development. BNDF-TrkB pathway has been found to be important for long-term potentiation in the hippocampus [25], hippocampal memory consolidation [26], and normal morphology of neurons [27]. We firstly found that anaesthesia with 1 MAC sevoflurane for $3 \mathrm{~h}$ increased BDNF and TrkB protein expression. These findings indicated that single exposure to $1 \mathrm{MAC}$ sevoflurane might enhance activation of the BDNF-TrkB pathway. However, anesthesia with 1 MAC 
sevoflurane for $6 \mathrm{~h}$ resulted in reduced levels of BDNF and TrkB. These findings suggested that single $(6 \mathrm{~h})$ exposure to sevoflurane inhibited the BDNF-TrkB pathway. Taken together, the current data indicated potential dual effects of sevoflurane on the BDNF-TrkB pathway.

Overall, short-term exposure to sevoflurane might produce neuroprotection via activation of the BDNF-TrkB pathway, while long-term exposure could induce neurotoxicity by repressing the BDNF-TrkB pathway. Interestingly, while shortterm $(3 \mathrm{~h})$ sevoflurane anaesthesia increased the levels of BDNF and TrkB, sevoflurane anaesthesia did not induce neuroprotection in primary cultured hippocampal neurons (Table 2). It is conceivable that short-term exposure to sevoflurane anaesthesia may only produce neuroprotection in case of brain insult. The findings that sevoflurane may have dual effects (neuroprotection or neurotoxicity) would be important to further determine the exact role of sevoflurane in brain function. In addition, BDNF-TrkB pathway could be one of the cellular mechanisms by which sevoflurane produce these dual effects. These findings suggested that regulation of BDNF-TrkB pathway by anaesthetics or other perioperative factors might affect brain function during surgery.

\section{Conclusion}

The effect of sevoflurane on hippocampal neurons in vitro is bidirectional which may be related to the time. Exposure to 1 MAC sevoflurane for3h, it showed a neuroprotective effect on hippocampal neurons, whereas the time is longer for $6 \mathrm{~h}$, it showed a neurotoxicity effect. And this result was related to the change of BDNF and TrkB protein expression, which was also called BDNF-TrkB pathway.

\section{Competing Interest}

The authors declare that they have no competing interests.

\section{Funding and Acknowledgment}

This work was supported by Subject of Hebei Provincial Department of health (20150222). The authors thank Subject of Hebei Provincial Department of health for support. The funders had no role in study design, data collection and analysis, decision to publish, or preparation of the manuscript.

\section{References}

1. Wang Y, Liu X, Li H. Incidence of the post-operative cognitive dysfunction in elderly patients with general anesthesia combined with epidural anesthesia and patientcontrolled epidural analgesia. Zhong Nan Da Xue Xue Bao Yi Xue Ban 2016; 41: 846-851.

2. Haseneder R, Starker L, Berkmann J, Kellermann K, Jungwirth B, Blobner M, Eder M, Kochs E, Rammes G. Sevoflurane anesthesia improves cognitive performance in mice, but does not influence in vitro long-term potentation in hippocampus CA1 stratum radiatum. PLoS One 2013; 8: 64732 .
3. Stratmann G, May LD, Sall JW, Alvi RS, Bell JS, Ormerod BK, Rau V, Hilton JF, Dai R, Lee MT, Visrodia KH, Ku B, Zusmer EJ, Guggenheim J, Firouzian A. Effect of hypercarbia and isoflurane on brain cell death and neurocognitive dysfunction in 7-day-old rats. Anesthesiology 2009; 110: 849-861.

4. Rappaport B, Mellon RD, Simone A, Woodcock J. Defining safe use of anesthesia in children. N Engl J Med 2011; 364: 1387-1390.

5. Zhou X, Song FH, He W, Yang XY, Zhou ZB, Feng X, Zhou LH. Neonatal exposure to sevoflurane causes apoptosis and reduces nNOS protein expression in rat hippocampus. Mol Med Rep 2012; 6: 543-546.

6. Sun L. Early childhood general anaesthesia exposure and neurocognitive development. $\mathrm{Br} \mathrm{J}$ Anaesth 2010; 105: 61-68.

7. Jevtovic-Todorovic V, Hartman RE, Izumi Y, Benshoff ND, Dikranian K, Zorumski CF, Olney JW, Wozniak DF. Early exposure to common anesthetic agents causes widespread neurodegeneration in the developing rat brain and persistent learning deficits. J Neurosci 2003; 23: 876-882.

8. Wilder R, Flick R, Sprung J, Katusic S, Barbaresi W, Mickelson C, Gleich S, Schroeder D, Weaver A, Warner D. Early exposure to anesthesia and learning disabilities in a population-based birth cohort. Anesthesiology 2009; 110: 796-804.

9. Satomoto M, Satoh Y, Terui K, Miyao H, Takishima K, Ito M, Imaki J. Neonatal exposure to sevoflurane induces abnormal social behaviors and deficits in fear conditioning in mice. Anesthesiology 2009; 110: 628-637.

10. Mashour GA. Consciousness and Anesthesia The Neurology of Conciousness (2nd Edn). Academic Press, San Diego 2016; 139-152.

11. Yamada K, Nabeshima T. Brain-derived neurotrophic factor/TrkB signaling in memory processes. J Pharmacol Sci 2003; 91: 267-270.

12. Brambrink AM, Evers AS, Avidan MS, Farber NB, Smith DJ, Zhang $\mathrm{X}$, Dissen GA, Creeley CE, Olney JW. Isoflurane-induced neuroapoptosis in the neonatal rhesus macaque brain. Anesthesiology 2010; 112: 834-841.

13. Sun Q, Xu Z, Ao H, Wang W, Fu W. In-vitro Primary Culture and Identification of Hippocampal Neurons from Newborn Rats. Trad Chinese Drug Res Clin Pharmacol 2010; 21: 461-464.

14. Landoni G, Rodseth RN, Santini F, Ponschab M, Ruggeri L, Szekely A, Pasero D, Augoustides JG, Del SP, Krzych LJ, Corcione A, Slullitel A, Cabrini L, Le Manach Y, Almeida RM, Bignami E, Biondi-Zoccai G, Bove T, Caramelli F, Cariello C, Carpanese A, Clarizia L, Comis M, Conte M, Covello RD, De Santis V, Feltracco P, Giordano G, Pittarello D, Gottin L, Guarracino F, Morelli A, Musu M, Pala G, Pasin L, Pezzoli I, Paternoster G, Remedi R, Roasio A, Zucchetti M, Petrini F, Finco G, Ranieri M, Zangrillo A. Randomized evidence for reduction of perioperative mortality. J Cardiothorac Vasc Anesth 2012; 26: 764-772. 
15. Ikonomidou C, Bosch F, Miksa M, Bittigau P, Vockler J, Dikranian K, Tenkova TI, Stefovska V, Turski L, Olney JW. Blockade of NMDA receptors and apoptotic neurodegeneration in the developing brain. Science 1999; 283: 70-74.

16. Ikonomidou C, Bittigau P, Ishimaru MJ, Wozniak DF, Koch C, Genz K, Price MT, Stefovska V, Horster F, Tenkova T, Dikranian K, Olney JW. Ethanol-induced apoptotic neurodegeneration and fetal alcohol syndrome. Science 2000; 287: 1056-1060.

17. Eibl JK, Strasser BC, Ross GM. Structural, biological, and pharmacological strategies for the inhibition of nerve growth factor. Neurochem Int 2012; 61: 1266-1275.

18. Kuan CY, Roth KA, Flavell RA, Rakic P. Mechanisms of programmed cell death in the developing brain. Trends Neurosci 2000; 23: 291-297.

19. Paule MG, Li M, Allen RR, Liu F, Zou X, Hotchkiss C, Hanig JP, Patterson TA, Slikker WJ, Wang C. Ketamine anesthesia during the first week of life can cause longlasting cognitive deficits in rhesus monkeys. Neurotoxicol Teratol 2011; 33: 220-230.

20. Bignami E, Biondi-Zoccai G, Landoni G, Fochi O, Testa V, Sheiban I, Giunta F, Zangrillo A. Volatile anesthetics reduce mortality in cardiac surgery. J Cardiothorac Vasc Anesth 2009; 23: 594-599.

21. Ikonomidou C: Blockade of NMDA receptors and apoptotic neurodegeneration in the developing brain. Science 1999; 283: 70-74.

22. Chen C, Ji M, Xu Q, Zhang Y, Sun Q, Liu J, Zhu S, Li W. Sevoflurane attenuates stress-enhanced fear learning by regulating hippocampal BDNF expression and Akt/
GSK-3beta signalling pathway in a rat model of posttraumatic stress disorder. J Anesth 2015; 29: 600-608.

23. Cozza A, Melissari E, Iacopetti P, Mariotti V, Tedde A, Nacmias B, Conte A, Sorbi S, Pellegrini S. SNPs in neurotrophin system genes and Alzheimer's disease in an Italian population. J Alzheimers Dis 2008; 15: 61-70.

24. Dudek H, Datta SR, Franke TF, Birnbaum MJ, Yao R, Cooper GM, Segal RA, Kaplan DR, Greenberg ME. Regulation of neuronal survival by the serine-threonine protein kinase Akt. Science 1997; 275: 661-665.

25. Liu X, Xue Q, Zeng Q, Li Q, Liu J, Feng X, Yu B. Sevoflurane impairs memory consolidation in rats, possibly through inhabiting phosphorylation of glycogen synthase kinase- $3 \beta$ in the hippocampus. Neurobiol Learn Mem 2010; 94: 461-467.

26. Lee JL, Everitt BJ, Thomas KL. Independent cellular processes for hippocampal memory consolidation and reconsolidation. Science 2004; 304: 839-843.

27. Baquet ZC, Gorski JA, Jones KR. Early striatal dendrite deficits followed by neuron loss with advanced age in the absence of anterograde cortical brain-derived neurotrophic factor. J Neurosci 2004; 24: 4250-4258.

\section{Correspondence to:}

Zhenming Dong

Department of Anesthesiology

Second Hospital of Hebei Medical University

PR China 